\title{
Role of Surface Melt and Icing Events in Livestock Mortality across Mongolia's Semi-Arid Landscape
}

\author{
Caleb G. Pan ${ }^{1, *(\mathbb{D})}$, John S. Kimball ${ }^{1}$, Munkhdavaa Munkhjargal ${ }^{2} \oplus$, Nathaniel P. Robinson ${ }^{3}$, \\ Erik Tijdeman ${ }^{2}$, Lucas Menzel ${ }^{2}$ and Peter B. Kirchner ${ }^{1,4}$ \\ 1 Numerical Terradynamic Simulation Group, WA Franke College of Forestry and Conservation, University of \\ Montana, Missoula, MT 59812, USA; john.kimball@umt.edu (J.S.K.); peter_kirchner@nps.gov (P.B.K.) \\ 2 Department of Geography, Heidelberg University, Heidelberg 69120, Germany; \\ munkhjargal@uni-heidelberg.de (M.M.); erik.tijdeman@uni-heidelberg.de (E.T.); \\ lucas.menzel@uni-heidelberg.de (L.M.) \\ 3 Panthera, New York City, NY 10018, USA; nrobinson@panthera.org \\ 4 Southwest Alaska Network Inventory and Monitoring Program, National Park Service, \\ Anchorage, AK 99501, USA \\ * Correspondence: caleb.pan@umt.edu or caleb.pan@mso.umt.edu
}

Received: 7 September 2019; Accepted: 14 October 2019; Published: 16 October 2019

\begin{abstract}
Livestock production is a socioeconomic linchpin in Mongolia and is affected by large-scale livestock die-offs. Colloquially known as $d z u d s$, these die-offs are driven by anomalous climatic events, including extreme cold temperatures, extended snow cover duration (SCD) and drought. As average temperatures across Mongolia have increased at roughly twice the global rate, we hypothesized that increasing cold season surface melt including soil freeze/thaw (FT), snowmelt, and icing events associated with regional warming have become increasingly important drivers of $d z u d$ events as they can reduce pasture productivity and inhibit access to grazing. Here, we use daily brightness temperature $\left(T_{b}\right)$ observations to identify anomalous surface melt and icing events across Mongolia from 2003-2016 and their contribution to $d z u d s$ relative to other climatic drivers, including winter temperatures, SCD, and drought. We find a positive relationship between surface melt and icing events and livestock mortality during the fall in southern Mongolia and during the spring in the central and western regions. Further, anomalous seasonal surface melt and icing events explain $17-34 \%$ of the total variance in annual livestock mortality, with cold temperatures as the leading contributor of $d z u d s(20-37 \%)$. Summer drought showed the greatest explanatory power (43\%) but overall had less statistically significant relationships relative to winter temperatures. Our results indicate that surface melt and icing events will become an increasingly important driver of $d z u d s$ as annual temperatures and livestock populations are projected to increase in Mongolia.
\end{abstract}

Keywords: Mongolia; snow cover; snow melt; freeze/thaw; climate change; passive microwave remote sensing

\section{Introduction}

Livestock production is a central part of Mongolia's economy [1], whereby the livelihoods of approximately half of the regional human population are connected to various forms of pastoralism $[2,3]$. Mongolia's large livestock population and its role as a national economic driver, enhances vulnerability to even small climatic fluctuations that can result in large annual livestock die-offs. In Mongolia, these anomalous die-off events are known as $d z u d s$, or wintertime disasters in the English language. Historically, dzud events played an important role in regulating livestock populations [4]. However, the intensity and frequency of $d z u d$ events have increased with growing livestock populations, reduced 
rangeland management, and accelerated climate change [5]. The largest recorded $d z u d$ event in the modern era occurred in 2010, where 8-10 million livestock perished in a single year [6,7]. Notably, the $2010 \mathrm{dzud}$ was preceded by three consecutive $d z u d s$ from 1999-2002 that resulted in the loss of 10-20 million livestock [8].

Through much of the 20th century, Mongolia was influenced by the Soviet Union, during which the government subsidized key resources enabling herders to cope with challenging climatic conditions, including well maintenance [9], and winter time hay and fodder storage [1], providing a necessary bridge for livestock to survive regional weather extremes and challenging climatic conditions. More recently, with the collapse of the Soviet Union and subsequent privatization of livestock ownership, livestock populations have precipitously increased; whereas formerly provided vital services and subsidies have been reduced, increasing herder vulnerabilities to $d z u d s$ [3]. In 1990, Mongolia had a livestock population of approximately 25 million and by 2016, its population increased over $200 \%$ to 60 million (Mongolia Statistical Service, 2017), straining Mongolia's social and ecological systems near their tipping points [10].

There are many different types of $d z u d s$ classified by different climatic and environmental conditions. The most studied $d z u d s$ include, but are not limited to, the tsagaan dzud (anomalously deep snow), khar dzud (extreme cold with snow), and khavsarcan dzud (combination of deep snow and extreme cold) [11]. The most devastating $d z u d$ events often occur during winters that follow summertime drought, where limited summertime precipitation decreases pastoral productivity, which reduces available hay and fodder storage needed to sustain animal fitness during subsequent periods of extreme weather conditions, including $d z u d s$ [4].

The magnitude of pastoral vulnerability to significant $d z u d$ events is a result of the interaction between climate, rangeland management, and governance, rather than just climatic events. However, perturbations in climatic conditions are the triggers of $d z u d$ events, manifested through or enhanced by multiple mechanisms, including: 1) summer droughts [7,12]; 2) below average winter temperatures [5]; and 3) above normal snowfall [13]. Few scientific efforts have examined the role and spatiotemporal heterogeneity of the tumer $d z u d$, defined as a significant snowmelt and subsequent icing event purported to be a major driver of livestock mortality in Mongolia [11]. Much less is known regarding the frequency and regional extent of the tumer $d z u d$ due to challenges in detecting such events [14,15]. Moreover, as Mongolia's annual temperatures are warming at roughly twice the global average rate [5] and wintertime temperatures are also increasing [16], wintertime snowmelt events [17] and the tumer dzud may become more common, leading to potentially greater risk of livestock die-offs within Mongolia.

Surface melt events are characterized by enhanced liquid water content (LWC) into the soil through freeze/thaw (FT) action or snowpack melt. Henceforth, we use 'melt events' to describe surface melt events for both FT dynamics and snowmelt events together. Accumulated snowpack LWC from melt events and/or rainfall can potentially freeze at the soil surface or on the overlying snowpack, forming a significant ice barrier to browsing wild and domestic ungulates, sometimes leading to large wintertime die-offs [18-20]. Fall and spring surface melt events from both freeze/thaw (FT) dynamics and snowmelt have also been found to reduce landscape productivity [21,22], which can inhibit herder abilities to fatten animals to a critical weight [4] moving into and out of an extreme winter. However, both wild and domestic reindeer populations in the Eurasian Arctic have been found to offset the negative impacts of icing events by adjusting movement and herding patterns to avoid impacted areas [20,23]. But in Mongolia, livestock have less freedom of movement due to rangeland management practices [2], limited herder preparedness and access to resources [4]. Remote sensing observations from current operational passive microwave (PM) and optical satellites provide an opportunity to reduce the risk of livestock mortality through detection and monitoring of anomalous melt events from the tumer dzud in Mongolia. 
Several studies have successfully examined the relationship between remotely sensed surface melt events on ungulate populations; including the application of QuickSCAT in the Russian Arctic [24] and passive microwave (PMW) in the Canadian Arctic Archipelago [25]. PMW remote sensing has become one of the most popular datasets in retrieving surface melt events due to its effectiveness in detecting changes in LWC of snow pack and twice-daily global image acquisition. At lower PMW frequencies, such as $19(\mathrm{~V}$ and $\mathrm{H}) \mathrm{GHz}$, brightness temperature $\left(\mathrm{T}_{\mathrm{b}}\right.$ ) will change with LWC but to a lesser degree than at 37 (V and H) GHz) [26]. The interaction between the surface's LWC and 19 and $37 \mathrm{GHz}$ has been utilized in a few different PMW driven algorithms to detect surface melt events including a diurnal amplitude variation $[27,28]$ and $a T_{b}$ differencing approach $[29,30]$. There have also been notable spectral gradient ratios developed, specifically the Gradient Ratio (GR) [18] and then elaborated on by [31] to create the Gradient Ratio Polarization (GRP) and has been observed to be a new and promising PMW technique to detect surface melt events [30].

In this paper we determine the spatiotemporal variability and trends in surface melt events across Mongolia using similar satellite $\mathrm{T}_{\mathrm{b}}$ retrievals from the Advanced Microwave Scanning Radiometers (AMSR-E and AMSR2) and Special Sensor Microwave Imager/Sounder (SSMI/S) [15,18,31] from October through April for water years (WY) 2003-2016 using the GRP. As $d z u d$ events stem from a complex interaction of multiple climatic forces, we examine the role of anomalous seasonal melt events as a contributor to $d z u d$ events in addition to cold temperatures, snow cover duration (SCD), and drought. This research clarifies the role of seasonal melt and icing events, and other climatic factors influencing the occurrence, extent and severity of $d z u d$ events. Several international groups and non-governmental organizations (NGOs) including the World Bank, United Nations, People in Need, and Save the Children, provide humanitarian aid during periods of severe $d z u d s$-including cash, livestock feed, veterinary services, medical provisions, and other necessary resources. Thus, we aim to provide a resource available to the Mongolian government and international NGOs for identifying regions in Mongolia that are more prone to specific types of $d z u d s$, to inform regional planning and risk mitigation.

\section{Geographical Context}

Mongolia is situated in the heart of the Asian landmass centrally located between Russia and China, creating a strong continental climate with extreme seasonal temperature variations and limited precipitation. January is the coldest month, with average temperatures ranging from $-15^{\circ} \mathrm{C}$ to $-35^{\circ} \mathrm{C}$. Average July temperatures are much warmer, ranging from $15^{\circ} \mathrm{C}$ in the mountains of the northern and western regions to between $20-25^{\circ} \mathrm{C}$ at lower elevations [5]. Winter precipitation in the region is limited by the Siberian High Pressure (SHP) zone [13,32] while summer precipitation is associated with the westerlies bringing moisture from the Atlantic and Mediterranean regions [33]. However, the majority of atmospheric moisture flow to Mongolia is blocked by surrounding mountain ranges, which creates strong regional gradients in annual precipitation ranging from 300-400 mm year ${ }^{-1}$ in the western and northern regions to $<100 \mathrm{~mm}_{\text {year }}{ }^{-1}$ in the central and southeastern areas [16]. Mongolia's ecoregions are dominated by arid deserts and shrublands (45\%) and temperate grasslands (39\%). The remaining $17 \%$ of Mongolia's landscape is comprised of temperate conifer forests (8\%), montane grasslands (5\%), and boreal forests (2\%) [34] (Figure 1). 


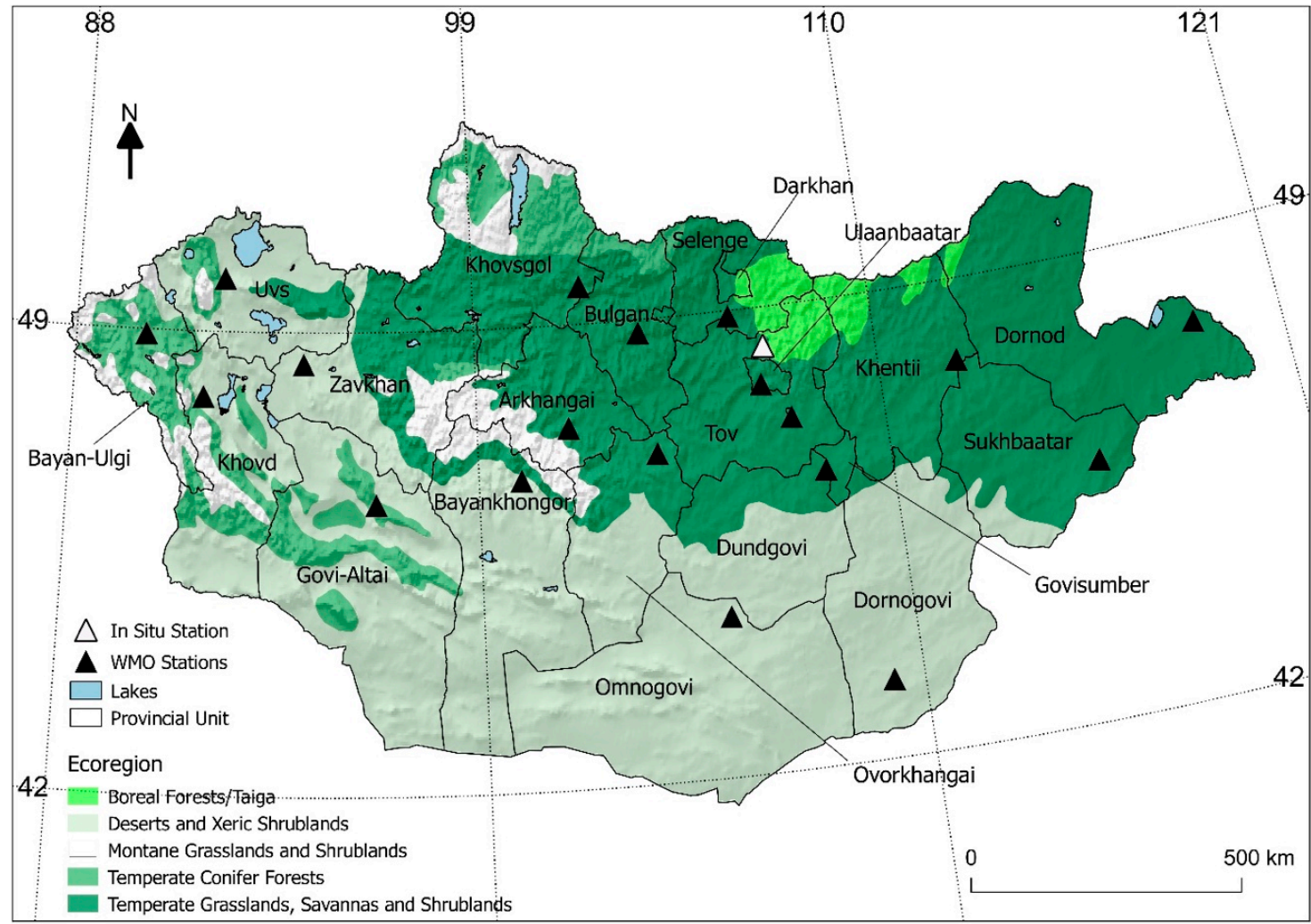

Figure 1. Reference map of Mongolia including the in situ climate station at Sugnugur Valley and other surface weather (WMO) stations. World Wildlife Federation (WWF) ecoregions and the boundaries of provincial units (i.e., aimags) are also shown.

\section{Materials and Methods}

\subsection{Satellite Datasets}

Mongolia is at the southern boundary of consistent daily image retrievals from polar orbiting passive microwave (PM) satellite sensors, which results in frequent gaps in the $T_{b}$ retrievals due to diverging sensor orbital swaths, particularly in the early portion of the satellite record. The daily $\mathrm{T}_{\mathrm{b}}$ coverage was improved after 2002 with the introduction of AMSR and SSMI/S sensors. For this reason, we defined our study period from WY 2003-2016. The AMSR-E sensor was launched on-board the NASA Aqua satellite and operated until 2011 [35]. The AMSR-2 follow-on mission was successfully launched in 2012 on-board the JAXA GCOM-W satellite and continues normal operations [36,37]. We used similar $\mathrm{T}_{\mathrm{b}}$ retrievals from SSMI/S on-board the Defense Meteorological Satellite Program (DMSP) F18 satellite platform to fill an approximate nine-month data gap in 2012 between the effective end of AMSR-E and beginning of the AMSR2 $\mathrm{T}_{\mathrm{b}}$ record. Daily AMSR-E $(18.7$ and $36.5 \mathrm{GHz})$ ascending retrievals $(1: 30 \mathrm{pm})$ and SSMI/S $(19$ and $37 \mathrm{GHz})$ evening retrievals $(6: 30 \mathrm{pm})$ were acquired from the NASA MEaSUREs calibrated enhanced-resolution PM daily EASE-GRID 2.0 ESDR V1 $\mathrm{T}_{\mathrm{b}}$ record mapped to a consistent $25 \mathrm{~km} \times 25 \mathrm{~km}$ global EASE-grid projection format [38]. Daily AMSR2 (18.7 and $36.5 \mathrm{GHz})$ ascending $\mathrm{T}_{\mathrm{b}}$ retrievals $(1: 30 \mathrm{pm})$ were acquired through the JAXA G-portal as Level 3 (L3) $\mathrm{T}_{\mathrm{b}}$ retrievals mapped to a similar $25 \mathrm{~km} \times 25 \mathrm{~km}$ resolution global grid (www.gportal.jaxa.jp/gpr).

\subsection{Ancillary Datasets}

We used the satellite Northern Hemisphere EASE-Grid 2.0 Weekly Snow Cover and Sea Ice Extent V4 $(25 \times 25 \mathrm{~km})$ product (Brodzik and Armstrong 2013) to derive annual SCD from WY 2003 to 2016. SCD is represented by Equation (1) [39] and calculated as the mean SCD for each aimag (provincial unit): 


$$
S C D=\sum_{\mathrm{i}=0}^{\mathrm{n}}\left(\mathrm{S}_{\mathrm{i}}\right)
$$

where $n$ is the number of days in a given $(W Y n=365)$, and $S_{i}$ is the extracted information from the binary snow cover information ( 0 no snow, 1 snow).

We extracted a Landsat-derived summer normalized difference vegetation index (NDVI) values for each aimag as a proxy for rangeland productivity [6]. We used mean NDVI values for August aggregated by aimag boundaries to represent summertime drought, such that, low NDVI values equate to reduced above ground biomass (AGB) from plant water stress [40]. Pasture productivity peaks in August in Mongolia and is followed by hay and fodder storage in September [2,41]. The use of the NDVI is preferred over other (meteorological) drought proxies as it directly reflects anomalies in vegetation health associated with drought. Here, we used the NDVI of the preceding summer to represent the rangeland productivity of a given water year (e.g., the NDVI of August 2002 is used for WY 2003). With respect to $d z u d s$, limited AGB in the late summer limits the amount of hay and fodder available for winter storage [41]. A detailed explanation of the NDVI record used for this study is available elsewhere [42].

Annual livestock data were acquired from the Mongolia Statistical Service (www.1212.mn) and include the total number annual livestock losses and total livestock population. We represented annual livestock losses in the statistical analysis as a Mortality Index (MI), calculated by creating a normalized ratio between livestock losses and the previous year's total livestock population for each aimag [43]. We demonstrate the historical changes in livestock populations across Mongolia (Figure 2a,b) and Dornod aimag in eastern Mongolia (Figure 2c,d). For both Mongolia and Dornod, the time series identifies significant livestock mortality events from 2000-2002 and 2010 (Figure 2). However, Dornod aimag observed additional substantial livestock mortality throughout the 1980s-demonstrating the spatial variability in livestock losses across Mongolia. We summarized all datasets used in the study in Table 1.

Table 1. Summary of datasets used in this study.

\begin{tabular}{|c|c|c|c|c|c|}
\hline Data & $\begin{array}{c}\text { Spatial } \\
\text { Resolution }\end{array}$ & $\begin{array}{l}\text { Temporal } \\
\text { Frequency }\end{array}$ & Platform/Sensors & Metrics & References/Source \\
\hline $\begin{array}{c}\text { MEaSUREs PMW Daily } \\
\text { EASE-Grid } 2.0 \\
\text { Brightness Temperature }\end{array}$ & $25 \mathrm{~km} \times 25 \mathrm{~km}$ & $12 \mathrm{~h}$ & $\begin{array}{l}\text { AMSR-E/2, } \\
\text { SSMIS }\end{array}$ & NA & Brodzick et al. 2016 \\
\hline $\begin{array}{l}\text { Northern Hemisphere } \\
\text { EASE-Grid Weekly Snow } \\
\text { Cover and Sea Ice Extent }\end{array}$ & $25 \mathrm{~km} \times 25 \mathrm{~km}$ & 7 day & $\begin{array}{l}\text { SMMR, SSM/I, } \\
\text { SSMIS, VAS }\end{array}$ & NA & Brodzick et al. 2013 \\
\hline NDVI & $30 \mathrm{~m}$ & Daily & Landsat & NA & Robinson et al. 2017 \\
\hline $\begin{array}{l}\text { World Meteorological } \\
\text { Organization }\end{array}$ & NA & Daily & NA & $\begin{array}{l}\text { Precipitation, } \\
\text { Temperature } \\
\text { air/surface }\end{array}$ & www.ncdc.noaa.gov \\
\hline In situ Climate station & NA & Daily & NA & $\begin{array}{l}\text { temperature, } \\
\text { precipitation, albedo, } \\
\text { wind speed }\end{array}$ & $\begin{array}{l}\text { Minderlein and } \\
\text { Menzel } 2014\end{array}$ \\
\hline Annual Livestock & NA & Annual & NA & Livestock count & www.1212.mn \\
\hline
\end{tabular}

\subsection{Climate Observations}

Meteorological observations from 49 climate stations distributed across Mongolia were acquired from World Meteorological Organization (WMO) global weather station daily records archived at the National Climate Data Center (NCDC) (www.ncdc.noaa.gov). Station measurements included daily average, minimum, and maximum surface air temperature, total precipitation, snow depth, and precipitation type observations. The in situ daily average temperature observations were used to derive regional mean annual winter temperatures for 19 of Mongolia's 21 aimags. We excluded the Govisumber and Darkhan Uul aimags from this study because they did not contain any WMO stations. 

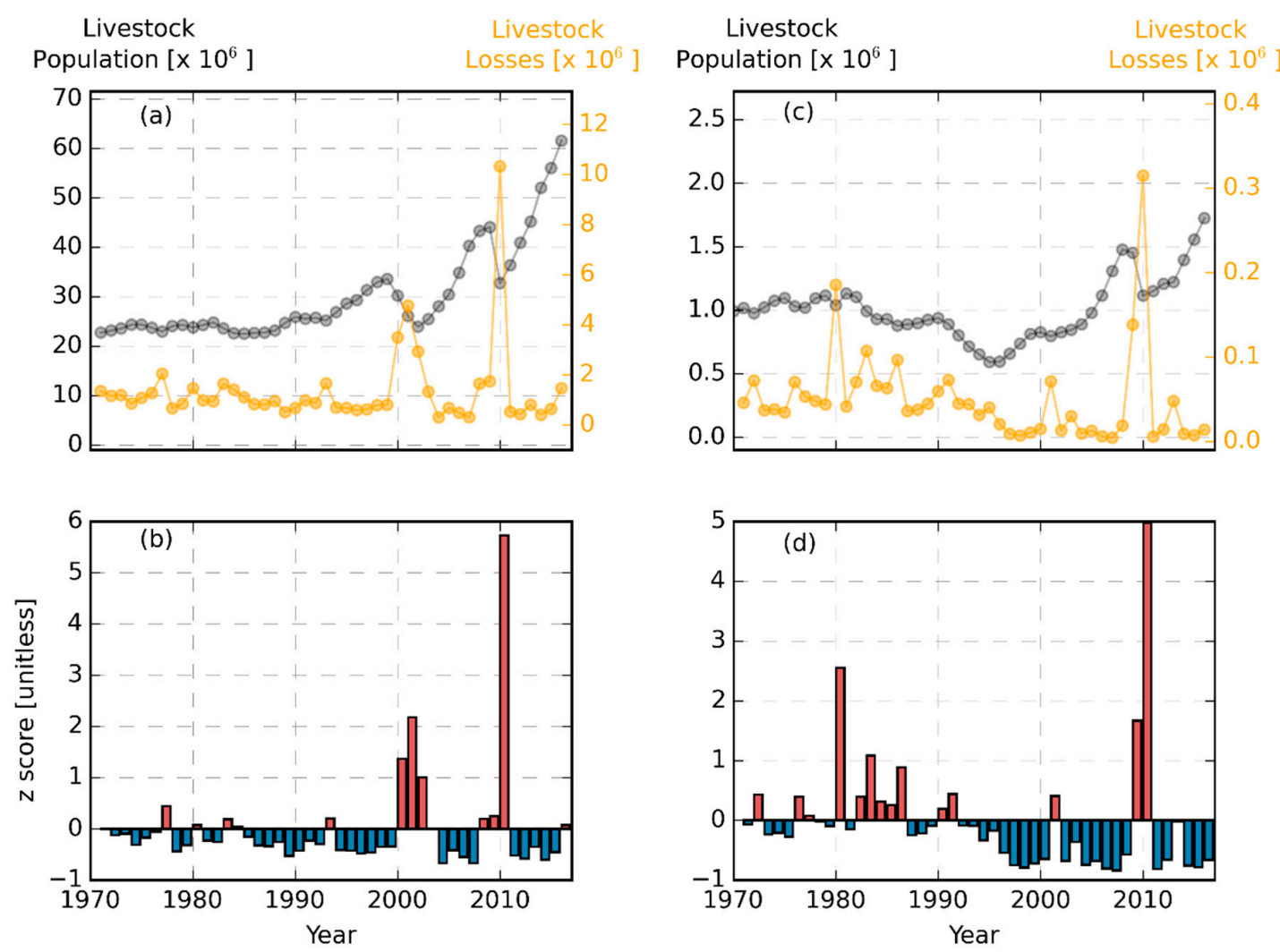

Figure 2. (a) Livestock population and losses for Mongolia from 1971-2016. (b) Standardized z-scores for annual livestock losses. (c) Livestock population and losses for Dornod aimag from 1971-2016. (d) Standardized z-scores for annual livestock losses in Dornod aimag. *Note the independent y-axis scales for each plot.

We selected one representative WMO station from each aimag (S1) and created a $50 \mathrm{~km} \times 50 \mathrm{~km}$ remote sensing sampling window around each station location. These windows were then used to extract and calculate daily mean $\mathrm{T}_{\mathrm{b}}$ values from the PM satellite record and averaged August NDVI values for each station location. Representative WMO stations were selected based on having a consistent temporal record matching the study period and being located near populated centers. Proximity to populated centers is important because herders often move livestock to these areas during the winter months to improve access to necessary resources.

In addition to the WMO stations, we also used a more comprehensive set of in situ meteorological measurements from a research station located approximately $100 \mathrm{~km}$ northwest of the Mongolian capital of Ulaanbaatar in the Sugnugur Valley. The station is located at the valley entrance in a transition zone between grassland and boreal forest on a southern exposed slope at 1,193m elevation (a.s.l., $48^{\circ} 26^{\prime} 55^{\prime \prime} \mathrm{N}, 107^{\circ} 11^{\prime} 41^{\prime \prime}$ E). The Sugnugur station has continuously collected measurements since spring 2012, including surface and air temperatures, precipitation, soil temperature, global and net radiation, wind velocity, and surface albedo [44,45]. We performed the same remote sensing sampling window selection at the Sugnugur Valley site to compare the satellite retrievals and collected in situ measurements.

\subsection{Detection of Melt Events}

Our approach to detect melt events builds upon a PM gradient ratio polarization (GRP) [31] algorithm developed from other studies $[15,25,31]$. The GRP algorithm exploits the differential response in microwave emissions between the $19(\mathrm{~V}, \mathrm{H}) \mathrm{GHz}$ and $37(\mathrm{~V}, \mathrm{H}) \mathrm{GHz}$ channels to changes in snow cover density and LWC within the snowpack surface. We first apply a spectral gradient ratio (GR) [18], which identifies distinct differences in the dielectric response at 19 and $37 \mathrm{GHz}$ to enhanced LWC in 
the surface snowpack; here, the LWC increase can result from either surface melt or rainfall. The GR is derived separately for both $\mathrm{V}$ and $\mathrm{H}$ polarized (pol) $\mathrm{T}_{\mathrm{b}}$ retrievals (Equation (2)).

$$
\operatorname{GR}\left(\operatorname{pol}_{(37,19)}\right)=\frac{\left[\mathrm{T}_{\mathrm{b}}(\mathrm{pol}, 37)-\mathrm{T}_{\mathrm{b}}(\text { pol, 19) }]\right.}{\left[\mathrm{T}_{\mathrm{b}}(\mathrm{pol}, 37)+\mathrm{T}_{\mathrm{b}}(\mathrm{pol}, 19)\right]}
$$

During periods of enhanced snowpack LWC, the GR from $H$ pol $T_{b}$ frequencies (GR-h) returned negative values and the V pol GR returned positive values (GR-v) [31]. The inverse relationship between the polarizations contributed to the development of a GRP (Equation (3)).

$$
\mathrm{GRP}=\frac{\mathrm{GR}-\mathrm{v}}{\mathrm{GR}-\mathrm{h}}
$$

Previous research has applied the GRP to a variety of satellite PM sensors including SMMR, SSM/I, and AMSR to detect rain-on-snow (ROS) and melt events in Quebec, the Canadian Arctic Archipelago (CAA), and Alaska $[15,25,31]$. These studies applied a global GRP threshold, ranging from less than 1 to -10 to classify ROS and melt events.

We found that the GRP had discrete characteristics sensitive to both atmospheric and surface conditions. In regions of persistent snow cover, the GRP ranges from around zero during periods of no snow to 1 during periods of snow cover. Yet, we observe deviations from both zero and 1 at higher snowpack LWC levels associated with ROS or FT events that can result in a range of GRP values from just under 1 to -10 , depending on the magnitude of such events (Figure 3). In our melt detection algorithm, rather than applying a global threshold, we set a GRP condition such that the GRP must be greater than 1 the day before the GRP is observed to be less than 1 . GRP values greater than 1 were assumed to coincide with snow cover (Figure 3). A detailed schematic for detecting melt events and validation can be found in Figure 4.

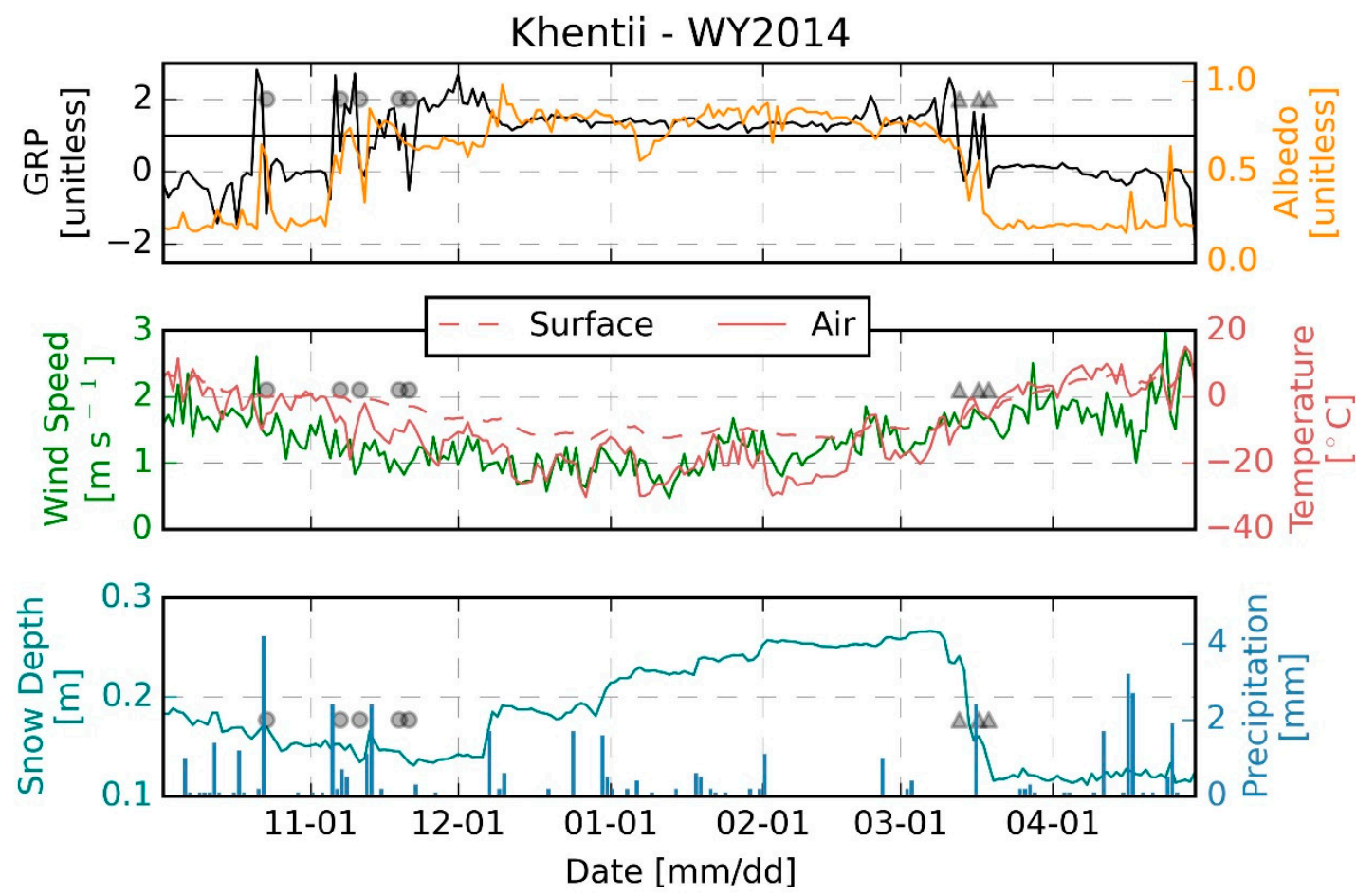

Figure 3. Satellite Gradient Ratio Polarization (GRP) time series plotted with in situ atmospheric and climatic parameters during selected Water Year (WY) 2014 from the Sugnugur valley (Khentii) site. The gray circles indicate fall surface melt events and the gray triangles indicate spring surface melt events. 


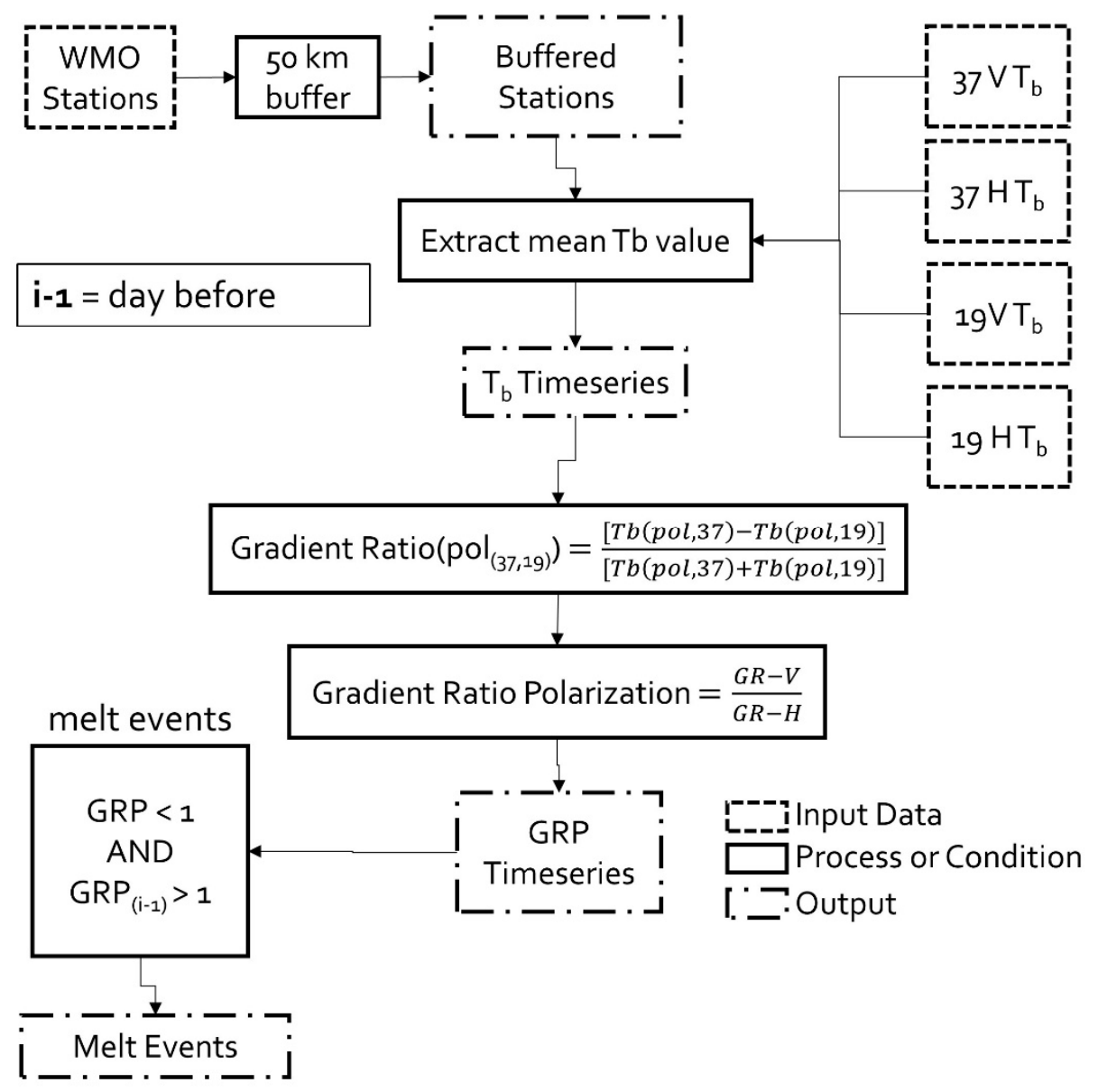

Figure 4. Workflow chart illustrating the steps required to detect surface melt events from the PMW $\mathrm{T}_{\mathrm{b}}$ retrievals. Each $\mathrm{T}_{\mathrm{b}}$ frequency $(19,37)$ and polarization $(\mathrm{V}, \mathrm{H})$ are averaged and processed separately before calculating the GRP Ratio.

\subsection{Statistical Analysis}

We performed temporal linear trend analysis to estimate the sign and strength of annual and seasonal trends in melt events at each WMO station location. Trends were calculated as the Theil-Sen (TS) slope computed as the median value between each paired point [46]. The TS is a robust trend estimator for non-parametric time series that do not meet the assumptions for data normality and homoscedasticity as well as resilient to outliers. Significant trends were identified using the Mann-Kendall Test (MKT) and were considered significant where $p<0.1$.

Pearson's correlation coefficient (Pearson's $r$ ) was used to determine the sign and strength of the relationship between the derived $d z u d$ proxies (melt events, SCD, summer NDVI, and winter temperatures) and MI. Results from the correlation and trend analyses were ranked based on their significance, ranging from relatively strong $(p \leq 0.05)$, to moderate $(0.05 \leq p<0.1)$ and weak $(p \geq 0.1)$ relationship categories [47].

We employed a stepwise general linear model (GLM) regression approach and Analysis of Covariance (ANCOVA) to determine the influence of each $d z u d$ proxy on annual livestock mortality represented by the proportion of explained variance (SS). We first tested the correlations between each $d z u d$ proxy to reduce potential collinearity within the GLM. We found high collinearity between each seasonal melt event proxy as well as between seasonal melt events and SCD $(r>0.6)$. We therefore created three separate GLM models, one for each respective melt season, and excluded SCD from all GLMs. We then ranked the models using a two-way stepwise approach with the Akaike Information Criterion (AIC), such that the ranked model that produced the lowest AIC was selected $[7,48]$. Lastly, 
ANCOVAs were performed on each seasonal model with the lowest AIC to calculate the proportion of explained variance.

\section{Results}

\subsection{Validation of the GRP Surface Melt Detection}

GRP time series extracted over the Sugnuguur Valley climate station correlated well with in situ surface albedo $(\mathrm{r}=0.73, p<0.001)$ and air temperature $(\mathrm{r}=-0.60, p<0.001)$ measurements. These two parameters were therefore used to evaluate the effectiveness of the GRP in detecting melt events. Figure 5a shows the relationship between daily surface albedo and the GRP for October through April. The plot portrays two distinct clusters, one where the GRP is below zero and albedo is less than 0.5 and another where the GRP is above 1 and albedo is greater than 0.5 . These two clusters indicate the relationship of the GRP and albedo during wet and dry snow conditions. In addition, this interaction indicates an albedo of 0.5 as a threshold to identify wet or dry snow conditions and verify GRP-detected melt events, similar to prior studies [49]. In the Sugnuguur Valley, the GRP algorithm detected 17 melt events from WY 2013-2016. Under the assumption that snow albedo decreased with enhanced LWC, we found that 11 of the GRP-detected melt events corresponded with a decrease in albedo from the previous day whilst the albedo was at least greater than 0.5 and resulted in an agreement of $65 \%$. Further, 235 days met our surface albedo requirement with no GRP melt events detected during the winter months with a persistent snow cover. In contrast, there were no days during fall and spring that met our albedo conditions that did not coincide with a GPR melt event.
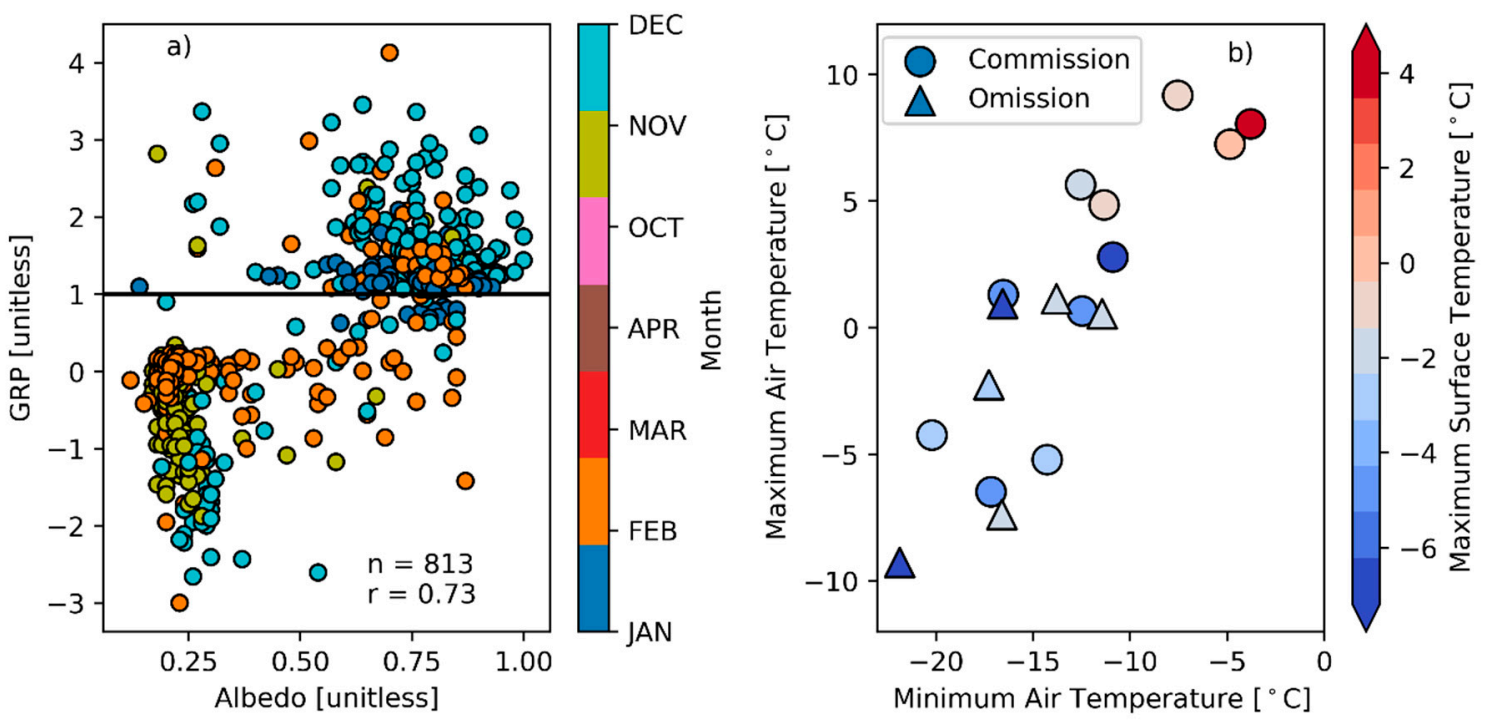

Figure 5. The left panel (a) plots in situ daily surface albedo at the Sugnuguur Valley site and collocated satellite PM-derived GRP values $(\mathrm{n}=813)$, colored by month. The right panel $(\mathbf{b})$ plots minimum and maximum temperature for 17 detected melt events at the same location.

In Figure $5 b$, we present the relationship of air and surface temperatures during each GRP-detected melt event. For the $11 \mathrm{GRP}$-detected melt events that were also identified using the in situ albedo criteria (commission), the mean minimum air temperature was $-12^{\circ} \mathrm{C}$. The five GRP-detected melt events that were not identified by the albedo criteria (omission) had a mean minimum air temperature of $-16^{\circ} \mathrm{C}$. The mean maximum temperature corroborates well with commission melt events at $2.1^{\circ} \mathrm{C}$ while the omission values had a mean maximum temperature of $-2.7^{\circ} \mathrm{C}$. Commission melt events also had a warmer mean maximum surface temperature relative to omission melt events of $-2.3^{\circ} \mathrm{C}$ and $-3.8^{\circ} \mathrm{C}$, respectively. Overall, the melt events occurred when mean air temperatures were approximately $-5.8 \pm 4.5^{\circ} \mathrm{C}$. These results are consistent with other studies documenting large air temperature 
variability during melt events, including temperatures extending below freezing $[15,31,50]$. However, the apparent temperature discrepancy may also reflect spatial scale differences between the in situ station measurements and overlying coarser $(50 \mathrm{~km} \times 50 \mathrm{~km})$ satellite data extraction window.

We also evaluated the GRP algorithm and associated melt events using other WMO station air temperature records within each aimag. We stratified the GRP-detected melt events by daily maximum surface air temperature $\left[{ }^{\circ} \mathrm{C}\right]$ including; $\mathrm{T}>0,0 \geq \mathrm{T}>-4,-4 \geq \mathrm{T}>-8$, and $\mathrm{T} \leq-8$ (Figure 6). The results showed that during the fall and spring, $82.5 \%$ of all GRP melt events occurred during days with a maximum surface air temperature greater than $0^{\circ} \mathrm{C}$, while the remaining $17.5 \%$ of melt events did not observe a temperature greater than $0^{\circ} \mathrm{C}$. However, during December and January, 76.1\% of the GRP melt events occurred on days when the maximum air temperature was below $-8^{\circ} \mathrm{C}$; these results suggest that changes in snowpack properties, including grain size, depth, and density, are being influenced through mechanisms other than surface air temperature such as snow redistribution, sublimation, and enhanced solar radiation [51-53].
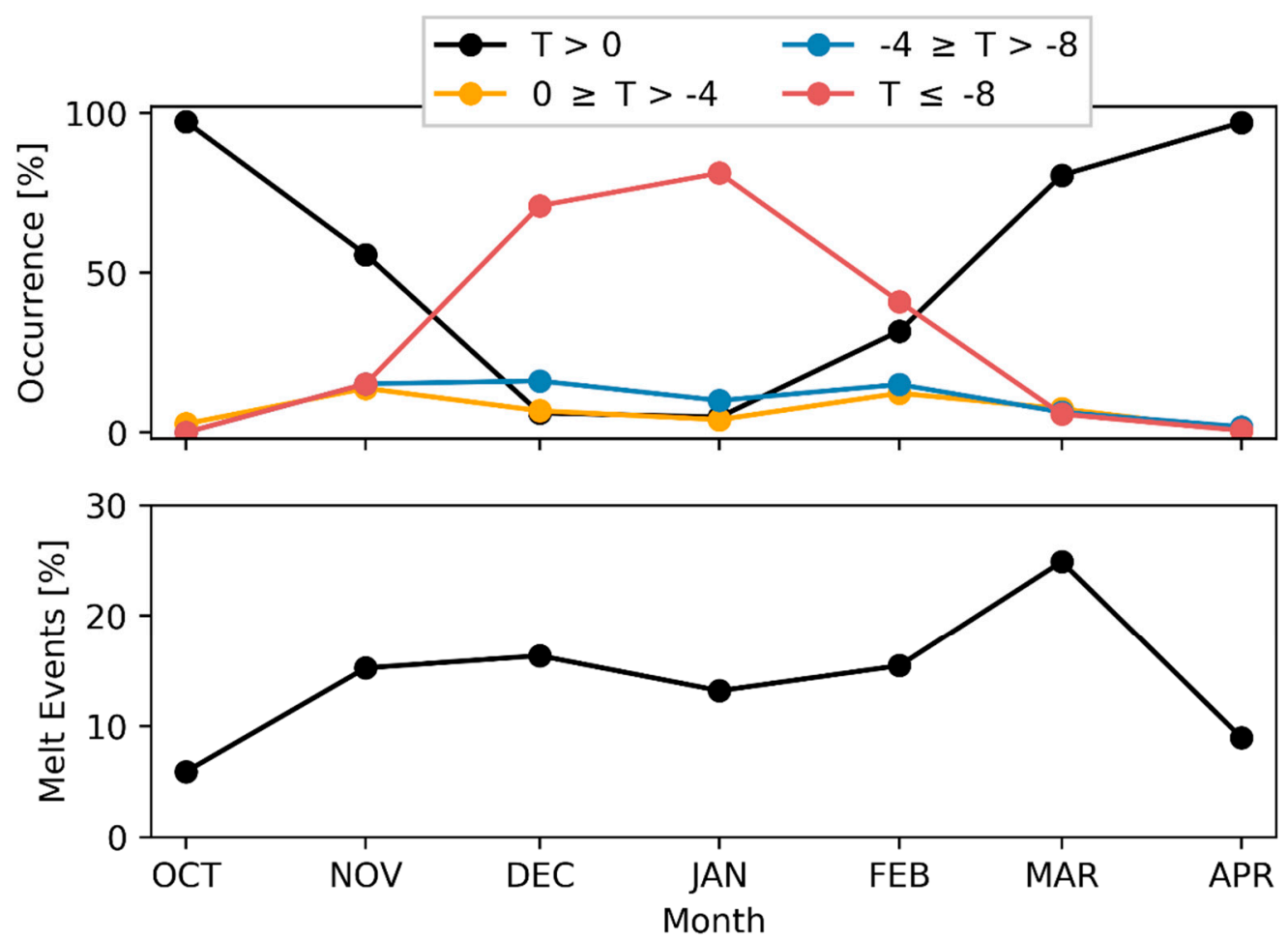

Figure 6. The percentage occurrence of GRP-detected melt events and coincident daily maximum air temperature are sorted by months across each WMO weather station (top). The monthly distribution of melt events detected at the WMO weather stations (bottom).

\subsection{Spatial Distribution of Seasonal Seasonal Melt Events}

The mean and coefficient of variation $\left(\mathrm{C}_{\mathrm{V}}\right)$ of satellite detected melt events in each Mongolian aimag during the fall (ON), winter (DJF), and spring (MA) months over the WY 2003-2016 period are shown in Figure 7. The number of melt events were relatively low in the fall, with a regional mean of 1.5 melt events year ${ }^{-1}$ over Mongolia and ranged from 0-3 melt events aimag ${ }^{-1}$ year $^{-1}$. The fall months had the highest mean $\mathrm{C}_{\mathrm{V}}$ at $117 \%$, indicating high inter-annual variability in melt events across all aimags relative to other seasons. Melt events were most common in the winter months, with a mean of 3 events year ${ }^{-1}$ and range from 1 to 6 events aimag $^{-1}$ year $^{-1}$ with the greatest number of winter melt events occurring in the mountainous region of western Mongolia. Approximately $45 \%$ of all annual melt events over the study period occurred during winter months, though March had the highest monthly proportion (25\%) of melt events congruent with the general onset of the spring thaw transition. Further, spring had a mean of 2.5 melt events year ${ }^{-1}$ and range from 1 to 5 events aimag $^{-1}$ 
year $^{-1}$, with the largest number of events occurring in the western and north central regions. There was also an increase in variability of spring melt events moving from the northwest to the southeast, where higher variability in the southeast results from sporadic snowfall and lack of persistent seasonal snow cover in the Gobi Desert.

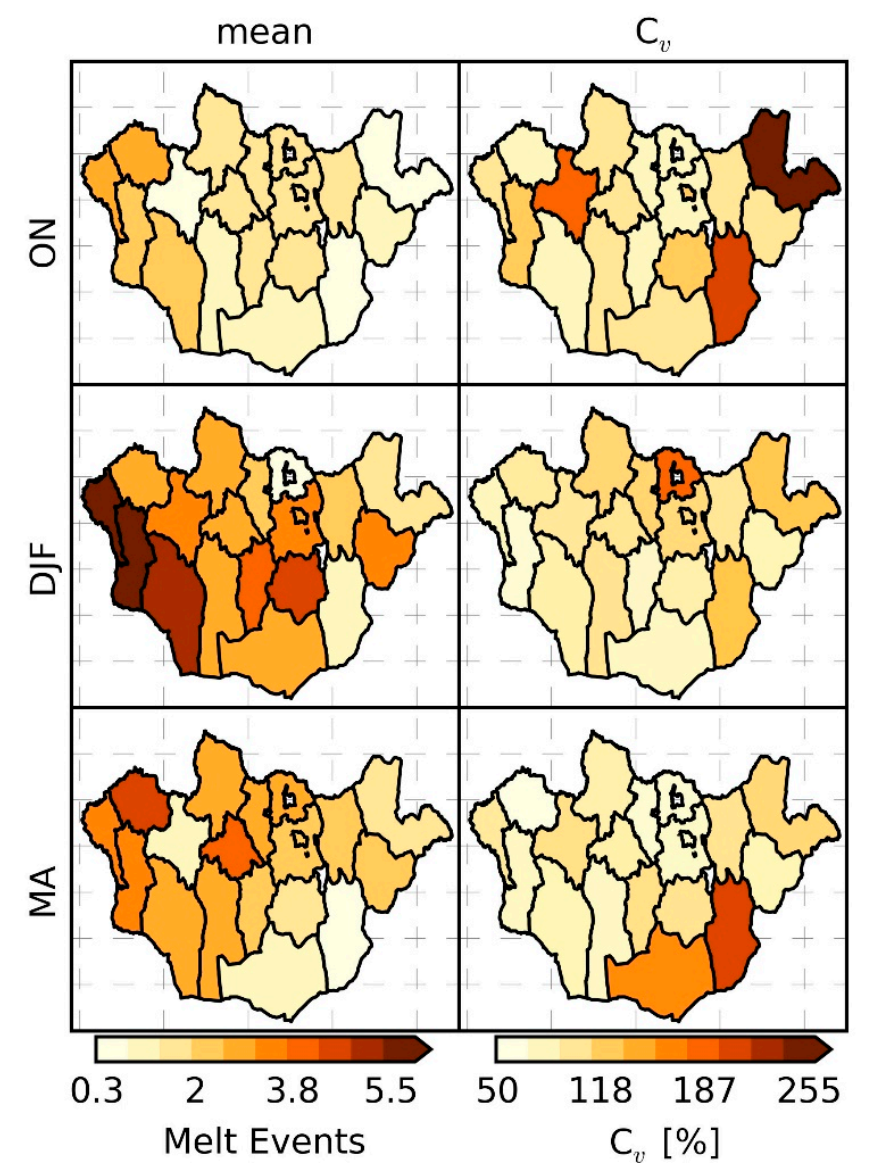

Figure 7. The mean and coefficient of variation $\left(\mathrm{C}_{\mathrm{V}}\right)$ in the number of anomalous melt events for each aimag and season during WY 2003-2016 in Mongolia; the images represent aggregated monthly results for fall (ON), winter (DJF) and spring (MA).

We estimated the sign and strength of melt event trends and their rates of change for each aimag using the MKT and Theil-Sen slope analyses, with results summarized in Figure 8. The results show a weak to moderate increasing melt trend in the fall, which may inhibit the development of persistent snow cover until later in the fall or early winter. In contrast, the number of winter melt events show a general declining trend. Our results showed both positive and negative trends in the number of spring melt events, with positive trends predominately occurring in western and central aimags characterized by more persistent winter snow cover. However, few of the seasonal trends were significant $(p \leq 0.1)$ due to the relatively short data record (13 years). 


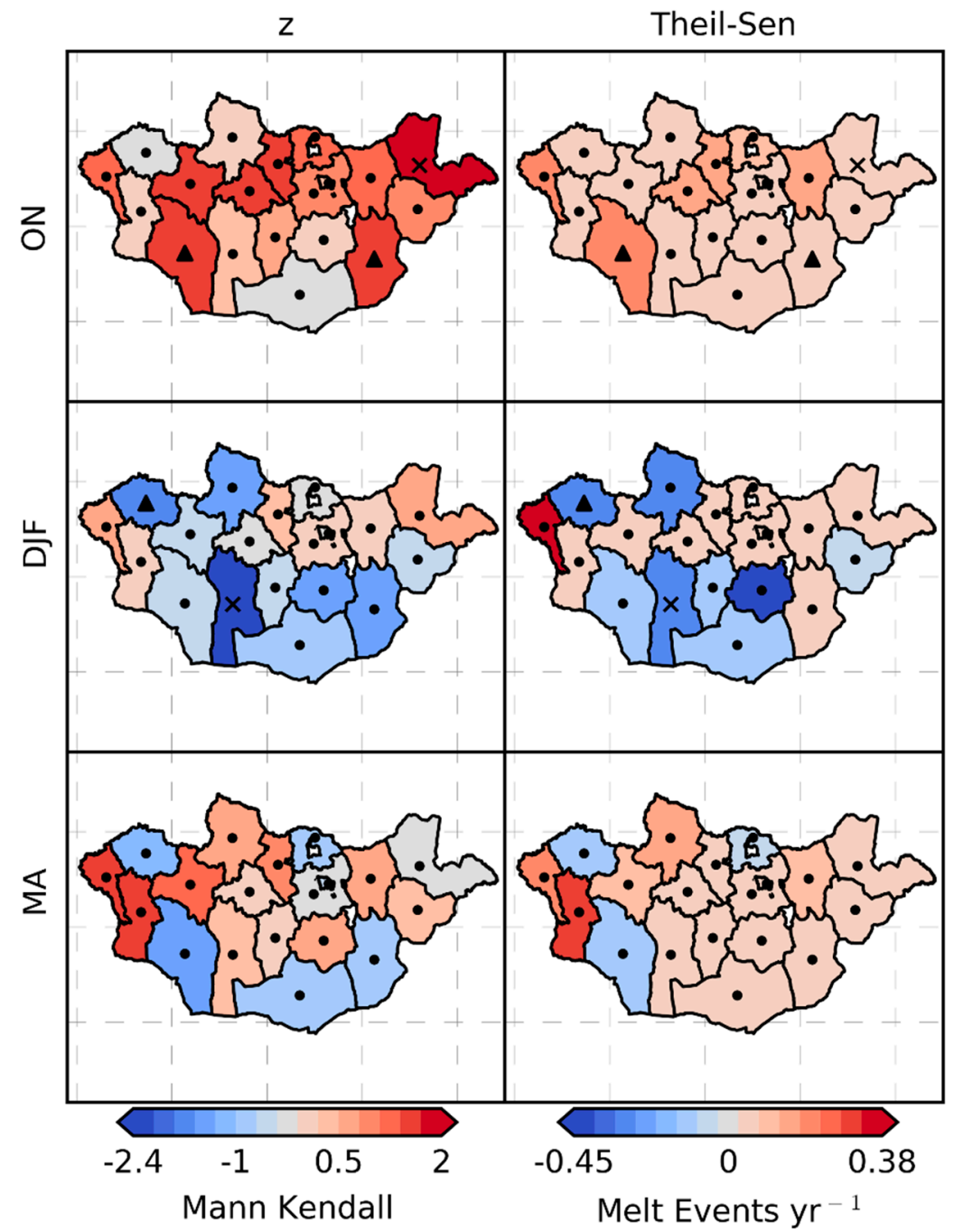

Figure 8. The normalized Mann-Kendall test statistic and Theil-Sen slope trends for melt events across Mongolia for WY 2003-2016. The black dots indicate weak correlations $(p>0.1)$, black triangles indicate moderate correlations $(0.05 \leq p<0.1)$ and the black ' $x$ ' symbols indicate stronger correlations $(p<0.05)$.

\subsection{Interactions between Climate Variables and Livestock Mortality}

The correlations and associated statistical significance between the MI and melt events are presented in Figure 9a-c. The calculated MI values were significantly and positively correlated with melt events across Mongolia, while the relative impact of melt events on mortality varied for different aimags and seasons. Four aimags showed strong to moderate relationships between the number of fall melt events and MI, with a mean correlation of $0.35(p<0.05)$. These aimags were predominantly located in the Gobi Desert, except for Khovsgol in northern Mongolia. Winter melt events corresponded with higher mortality in only three aimags, with a mean correlation of $0.36(p<0.05)$. In contrast, spring melt events were strongly correlated to annual livestock mortality in nine aimags, which represented $47 \%$ of the analyzed aimags and showed a mean correlation of $0.39(p<0.05)$. Six western and central aimags showed the strongest correlations between spring melt events and livestock mortality (mean correlation of $0.46, p<0.02$ ). 


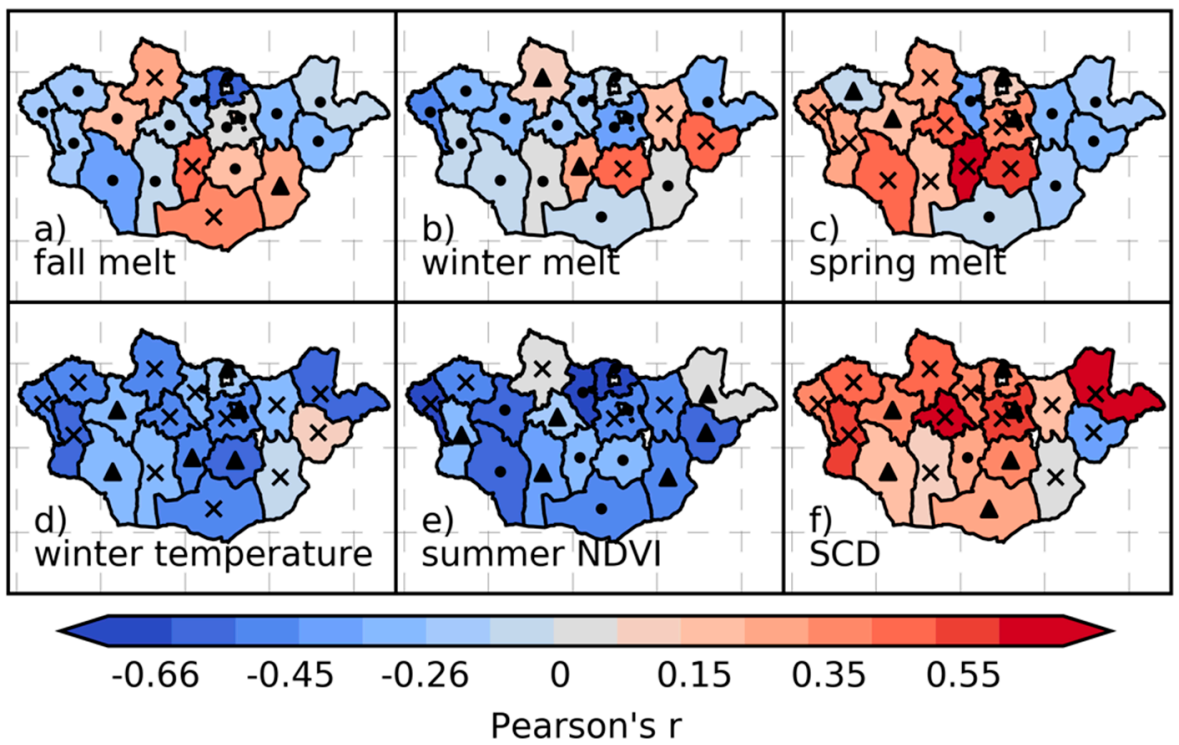

Figure 9. Correlations between $d z u d$ climate proxies and MI for WY 2003-2016. The black dots indicate weak correlations $(p>0.1)$, black triangles indicate moderate correlations $(0.05 \leq p<0.1)$ and the black ' $\mathrm{x}$ ' symbols indicate strong correlations $(p<0.05)$.

To clarify the role of seasonal melt events relative to other $d z u d$ climatic drivers, we present the correlations and significance of the relationships between MI and winter temperatures (f), summer NDVI (e), and SCD (f) in Figure 9d-f. The annual MI was generally inversely proportional to both winter temperature and summer NDVI (used as a proxy for rangeland productivity). Specifically, colder winter temperatures corresponded with a higher MI $(\mathrm{r}=-0.39)$ while years with lower summer NDVI also coincided with higher mortality $(\mathrm{r}=-0.55, p<0.05)$ in 18 of the 19 aimags examined. The MI was also directly proportional to SCD in 17 aimags $(r=0.38, p<0.05)$ and the strongest correlations were found across eight aimags in north-central and western Mongolia $(r=0.51, p<0.01)$, whereby years with longer SCD coincide with greater livestock losses.

We next contextualized the role of melt events relative to other climatic $d z u d$ drivers by quantifying the relative contribution of each climatic driver to annual livestock mortality using a GLM regression framework. Due to collinearity between seasonal melt events, three separate GLM models were created, one for each respective season. Collinearity also existed between SCD and melt events, so we excluded SCD from all GLM models. The percent of total variance in the MI explained by each GLM and environmental factor is presented in Figure 10. Fall melt events explained $13-27 \%$ of the total variance in MI in five aimags and were significant $(p<0.1)$ in Selenge and Uvs. Spring melt events explained $16-24 \%$ of the variance in MI in five aimags and were significant $(p<0.1)$ in Bulgan, Govi-Altai, Khentii, and Ovorkhanghai. Winter melt events had less explanatory power relative to fall and spring but were able to explain $23 \%(p<0.1)$ of the variance in MI in Sukhbaatar (Table S3a-c).

Winter temperatures and summer NDVI generally had greater influence on annual livestock mortality than seasonal melt events. However, fall melt events explained more variance in annual livestock losses than either winter temperatures or summer NDVI in the Selenge aimag. Moreover, for each GLM, winter temperature consistently had the most significant results $(p<0.05)$ and accounted for 21 to $37 \%$ of the total variance in annual MI. Summer NDVI was a significant $(p<0.05)$ predictor of annual mortality predominantly in the western regions, as well as the Sukhbaatar and Dundgovi aimags in eastern Mongolia. Summer NDVI also explained 26 to $47 \%$ of the total variance in annual livestock mortality in the spring melt model, with the strongest correspondence in Selenge and Zavkhan aimags of north-central and western Mongolia, respectively. 


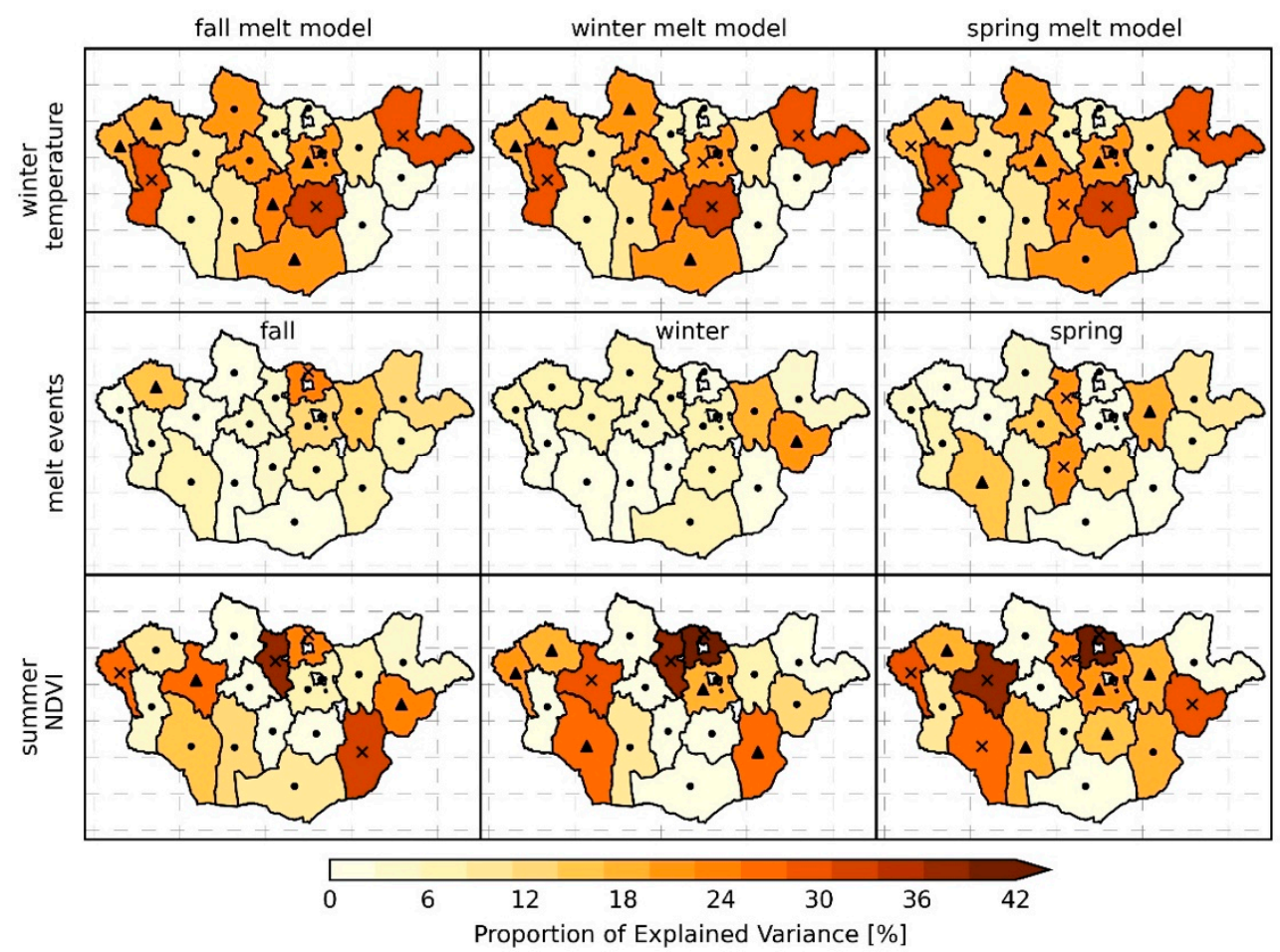

Figure 10. GLM results for the fall, winter, and spring. For each model, the proportion of total variance in annual MI explained by each environmental factor is represented. Black dots indicate weak correlations $(p>0.1)$, black triangles indicate moderate correlations $(0.05 \leq p<0.1)$ and the black ' $\mathrm{x}^{\prime}$ symbols indicate strong correlations $(p<0.05)$.

The $d z u d s$ of 2010 were among the most devastating livestock mortality events in recent decades in which 10.2 million livestock perished across Mongolia (Mongolia Statistical Service 2017). The five environmental factors examined in this study and the reported annual livestock losses are presented for the $2010 \mathrm{dzud}$ as standardized anomalies from the long-term (2003-2016) record in Figure 11a-f. Here, the livestock mortality anomaly in 2010 for Sukhbaatar in eastern Mongolia is very low because of a $d z u d$ event in 2008 that elevated morality and resulted in a $25 \%$ decline in total livestock. Dornogovi to the south of Sukhbaatar, also shows a low livestock loss anomaly due to a large die-off event in 2006 , which contributed to a decline of $18 \%$ in total livestock. These results show that the number of fall melt events in 2010 was anomalously high in the southern Gobi and some aimags in northern Mongolia. In addition, the number of spring melt events and SCD were anomalously high in the central and western aimags. Winter temperatures and summer NDVI were also anomalously low in 2010. Each of these factors alone promotes mortality, while their combined effects reinforce one another in contributing to the dramatic livestock losses in 2010. These results suggest that the most severe $d z u d$ events in Mongolia are a potent combination of cold winter temperatures, summer drought, and both enhanced snow duration and melt events. 


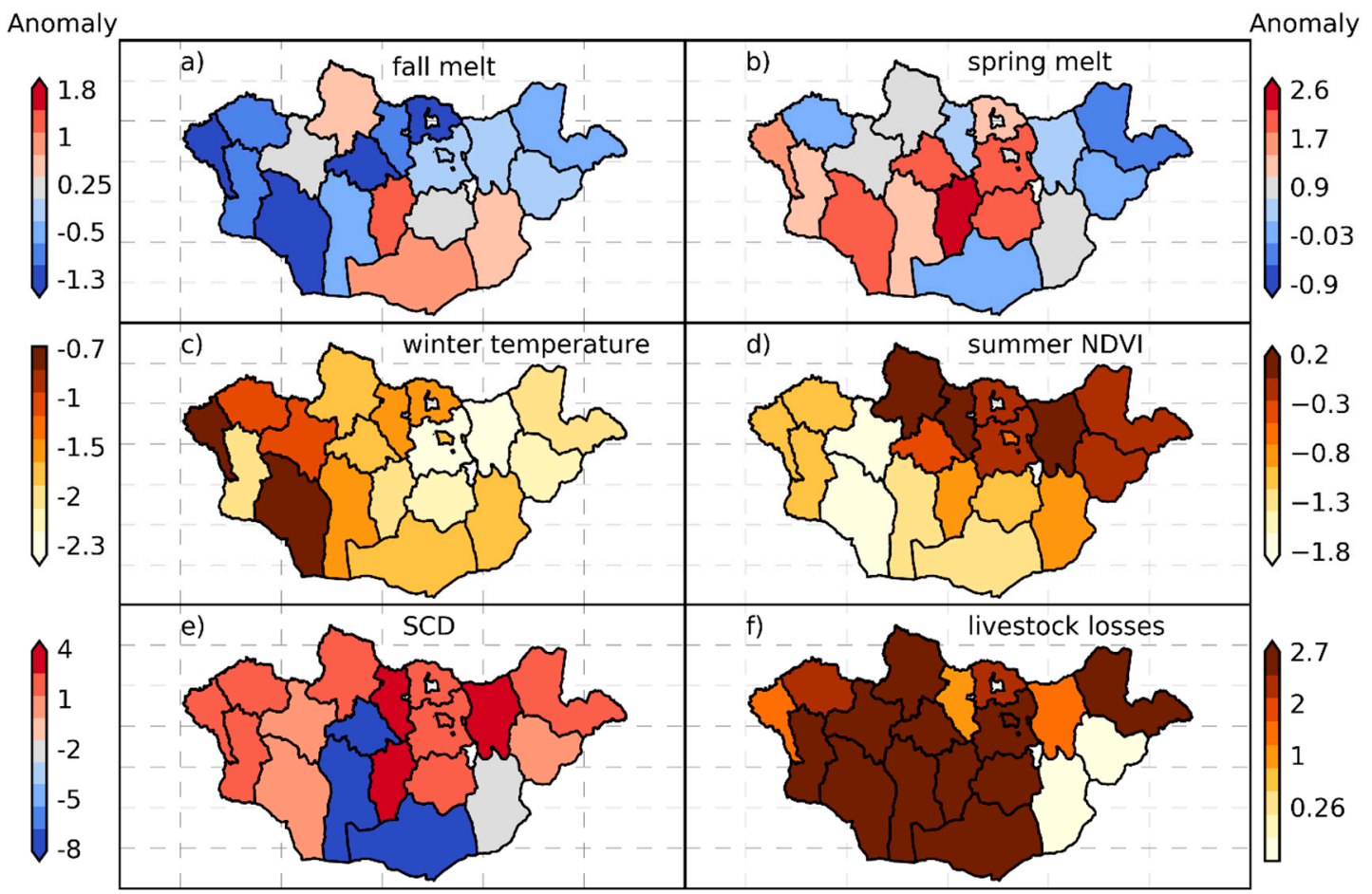

Figure 11. Standardized anomalies for fall melt events (a), spring melt events (b), winter temperature (c), summer NDVI (d), snow cover duration (SCD) (e), and livestock losses (f) during the dzud of 2010. Winter melt events are not included in the figure because they were only significantly correlated with a small number aimag livestock losses in 2010.

\section{Discussion}

\subsection{Snow and Climate Interactions in Mongolia}

Our results on the detection of anomalous melt events from satellite PM observations across Mongolia improve our understanding of the role that these events and other environmental factors have on $d z u d$ risk across the region. Our findings are consistent with other studies indicating that anomalously cold winter temperatures are the leading contributor to $d z u d s[7,41,54,55]$. However, our results also reveal that anomalous fall melt events contribute significantly to annual livestock mortality in the southern aimags of the Gobi Desert, while spring melt events are significant contributors to livestock mortality in the western and central aimags.

The impact of future melt events on livestock mortality will be influenced by the response of seasonal snow cover to continued climate change. There has been an observed increase in Eurasian snow cover over the past two decades, largely attributed to a weakening of the polar vortex [56] although this weakening has not equated to enhanced snow cover in Mongolia, which is consistent with a recent study of snow cover trends over the Tibetan Plateau from 2000-2015 [57]. However, our results indicate increasing trends in anomalous fall melt events over Mongolia, which may inhibit the development of a persistent snowpack and extend the periods of intermittent regional snow cover. These changes can promote snow conditions that adversely affect livestock, suggesting that more detailed snow structural data beyond the simple SCD metric are needed to better diagnose climatically driven modulations in snow cover characteristics and their influence on livestock mortality in the semi-arid environments of Mongolia.

Climate warming in Mongolia [5] will likely increase the frequency of anomalous melt events [15]. This warming will shift the regional precipitation regime towards more convective activity during fall, winter, and spring across Eurasia [58]. Warmer air temperatures coupled with more frequent and intense convective activity is expected to enhance radiative melting events in the region; yet the 
impact of these changes on ecosystem processes and services, and livestock mortality risk in Mongolia remain uncertain.

\subsection{Assumptions and Limitations}

The GRP-derived melt events detected from satellite PM remote-sensing can represent a range of different surface conditions, including anomalous snowmelt and refreezing where a significant snowpack is present or an abrupt surface thaw and refreeze (FT) or icing event where sufficient surface moisture variation is present to produce a strong PM signal [15,59]. Thus, the surface conditions represented by the GRP defined melt events and their impact on livestock mortality may vary for different regions and climate conditions across Mongolia. This study is also limited in our capabilities to validate surface melt events across the landscape because we are currently limited to air temperature from WMO stations. Potential exists in using more comprehensive metrics including the normalized difference in air and ground temperatures [60] and changes in volumetric water content [61]. The possibility for the derivation of these metrics is increasing as Mongolia continues to develop their borehole and climate monitoring networks $[62,63]$.

Our GLMs and the results from other studies are not able to fully explain livestock mortality using only environmental variables [7,54,55] because $d z u d$ events in Mongolia are caused by a combination of physical, biological, socioeconomic and institutional factors $[4,41,64,65]$. Governance and socioeconomic factors should be included in future studies contributed through herder interviews and surveys to provide a more robust understanding of how surface melt and icing events influence livestock management at local and regional scales.

The assumptions and simplifications in our GLMs likely contributed to model uncertainty as described here. The derivation of melt events is acquired from satellite PM retrievals within a $50 \times 50 \mathrm{~km}$ window overlying a single long-term climate monitoring station located near a municipal center in each aimag. Given that some aimags encompass over $60,000 \mathrm{~km}^{2}$ [7], the detection of melt events may not be representative of landscape heterogeneity within an aimag. However, during the winter months, herders often relocate to smaller aimag provincial units (soums) or city centers to increase access to resources [64]. Hence, the local station may more closely represent environmental conditions that a greater number of livestock experienced during the winter months. In addition, reported livestock losses are based on an annual census acquired in December that does not record the reason for mortality losses; this can lead to model uncertainty because we assume that the years with significant livestock losses reflect anomalous climate conditions rather than other possible factors including predation, isolated disease outbreaks, or inexperienced herders [7].

\section{Conclusions}

This study identified the seasonal and spatial pattern in anomalous surface melt events detected from satellite PMW remote sensing and the relative contribution of these events to annual livestock mortality across Mongolia. Whether fall and spring melt events impact livestock through subsequent icing events $[18,66]$ or the degradation of landscape productivity [21,22] remains undetermined. Regardless, we also found that in some regions, melt events explained between $18-34 \%$ of the total variance in annual livestock die-offs-demonstrating their importance relative to other climatic variables. We suggest incorporating quantitative remote sensing with in situ interviews and targeted surveys to gain a stronger understanding of how melt events influence livestock populations across Mongolia. Yet, in general, our results agreed with others that suggested the importance of cold temperatures, summer drought, and SCD on livestock mortality as well as the spatial and temporal variability in these climatic drivers. However, as Mongolia's temperatures and convective precipitation is predicted to increase into the future, seasonal melt events will also likely increase, placing greater demands on informed regional planning and governance to mitigate increased $d z u d$ and livestock mortality risk. 
Supplementary Materials: The following are available online at http://www.mdpi.com/2072-4292/11/20/2392/s1, Table S1: Selected aimag WMO stations used to extract satellite $\mathrm{T}_{\mathrm{b}}$ and snow cover retrievals, and evaluate estimated melt events and SCD, Table S2a-c: GLM model outputs for the fall (a), winter (b), and spring (c) models. Each table includes the $\mathrm{p}$-value and the proportion of variance each predictor explains (SS), Figure S1: Comparison of PM calculated SCD and in situ SCD.

Author Contributions: C.G.P., J.S.K., M.M., conceived and designed the project. C.G.P., M.M., N.P.R., and E.T. performed the analysis. L.M. and M.M. provided the in situ data observations. All authors contributed to the writing of this paper.

Funding: C.G.P. was funded by a German Academic Exchange Research Grant (DAAD) and the U.S. Department of State's Fulbright Program. Portions of this work were also funded by NASA (80NSSC18K0980).

Acknowledgments: We thank the four anonymous reviewers for their constructive comments in making this a stronger paper.

Conflicts of Interest: The authors declare no conflict of interest.

\section{References}

1. Fernández-Giménez, M.E. Sustaining the Steppes: A Geographical History of Pastoral Land Use in Mongolia. Geogr. Rev. 1999, 89, 267-290. [CrossRef]

2. Johnson, D.; Sheehy, D.; Miller, D.; Damiran, D. Mongolian rangelands in transition. Secheresse 2006, 17, 133-141.

3. Sternberg, T.Ã. Environmental challenges in Mongolia's dryland pastoral landscape. J. Arid Environ. 2008, 72, 1294-1304. [CrossRef]

4. Fernández-Giménez, M.E.; Batkhishig, B.; Batbuyan, B. Cross-boundary and cross-level dynamics increase vulnerability to severe winter disasters (dzud) in Mongolia. Glob. Environ. Chang. 2012, 22, 836-851. [CrossRef]

5. Batima, P.; Natsagdorj, L.; Gombluudev, P.; Erdenetsetseg, B. Observed Climate Change in Mongolia. AIACC Work. Pap. 2005, 25.

6. Hilker, T.; Natsagdorj, E.; Waring, R.H. Satellite observed widespread decline in Mongolian grasslands largely due to overgrazing. Glob. Chang. Biol. 2014, 20, 418-428. [CrossRef]

7. Rao, M.P.; Davi, N.K.; D'arrigo, R.D.; Skees, J.; Nachin, B.; Leland, C.; Lyon, B.; Wang, S.-Y.; Byambasuren, O. Dzuds, droughts, and livestock mortality in Mongolia. Environ. Res. Lett. 2015, 10, 74012. [CrossRef]

8. Pederson, N.; Hessl, A.E.; Baatarbileg, N.; Anchukaitis, K.J.; Di Cosmo, N. Pluvials, droughts, the Mongol Empire, and modern Mongolia. Proc. Natl. Acad. Sci. USA 2014, 111, 4375-4379. [CrossRef]

9. Sugita, M.; Yoshizawa, S.; Byambakhuu, I. Limiting factors for nomadic pastoralism in Mongolian steppe: A hydrologic perspective. J. Hydrol. 2015, 524, 455-467. [CrossRef]

10. Fernández-giménez, M.E.; Venable, N.H.; Angerer, J.; Fassnacht, S.R.; Reid, R.S.; Khishigbayar, J. Exploring Linked Ecological and Cultural Tipping Points in Mongolia. Anthropocene 2016, 17, 46-69. [CrossRef]

11. Hahn, H.A. Mongolian Dzud: Threats to and Protection of Mongolia's Herding Communities. 2017. Available online: http://aas2.asian-studies.org/EAA/EAA-Archives/22/2/1486.pdf (accessed on 16 October 2019).

12. Sternberg, T.; Thomas, D.; Middleton, N. Short Communication Drought dynamics on the Mongolian steppe, 1970-2006. Int. J. Climatol. 2011, 31, 1823-1830. [CrossRef]

13. Shinneman, A.L.C.; Umbanhowar, C.E.; Edlund, M.B.; Soninkhishig, N. Late-Holocene moisture balance inferred from diatom and lake sediment records in western Mongolia. Holocene 2010, 20, 123-138. [CrossRef]

14. Rennert, J.K.; Roe, G.; Putkonen, J.; Bitz, C.; Russell, D.E.; Wallace, J.M. Soil Thermal and Ecological Impacts of Rain on Snow Events in the Circumpolar Arctic. J. Clim. 2009, 22, 2302-2315. [CrossRef]

15. Pan, C.G.; Kirchner, P.; Kimball, J.S.; Kim, Y.; Du, J. Rain-on-snow events in Alaska, and their frequency and distribution from satellite observations. Environ. Res. Lett. 2018, 13, 075004. [CrossRef]

16. Shinneman, A.L.C.; Almendinger, J.E.; Umbanhowar, C.E.; Edlund, M.B.; Nergui, S. Paleolimnologic evidence for recent eutrophication in the valley of the great lakes (Mongolia). Ecosystems 2009, 12, 944-960. [CrossRef]

17. Cohen, J.; Ye, H.; Jones, J. Trends and variability in rain-on-snow events. Geophys. Res. Lett. 2015, 42, 1-8. [CrossRef]

18. Grenfell, T.C.; Putkonen, J. A method for the detection of the severe rain-on-snow event on Banks Island, October 2003, using passive microwave remote sensing. Water Resour. Res. 2008, 44, 1-9. [CrossRef] 
19. Riseth, J.Å.; Tømmervik, H.; Helander-Renvall, E.; Labba, N.; Johansson, C.; Malnes, E.; Bjerke, J.W.; Jonsson, C.; Pohjola, V.; Sarri, L.-E.; et al. Sámi traditional ecological knowledge as a guide to science: Snow, ice and reindeer pasture facing climate change. Polar Rec. 2011, 47, 202-217. [CrossRef]

20. Loe, L.E.; Hansen, B.B.; Stien, A.; Albon, S.D.; Bischof, R.; Carlsson, A.; Irvine, R.J.; Meland, M.; Rivrud, I.M.; Ropstad, E.; et al. Behavioral buffering of extreme weather events in a high-Arctic herbivore. Ecosphere 2016, 7, 1-13. [CrossRef]

21. Chen, X.; Liang, S.; Cao, Y.; He, T.; Wang, D. Observed contrast changes in snow cover phenology in northern middle and high latitudes from 2001-2014. Sci. Rep. 2015, 5, 16820. [CrossRef] [PubMed]

22. Bokhorst, S.F.; Bjerke, J.W.; Tømmervik, H.; Callaghan, T.V.; Phoenix, G.K. Winter warming events damage sub-Arctic vegetation: Consistent evidence from an experimental manipulation and a natural event. J. Ecol. 2009, 97, 1408-1415. [CrossRef]

23. Bartsch, A.; Kumpula, T.; Forbes, B.; Sammler, F. Detection of snow surface thawing and refreezing in the Eurasian Arctic with QuikSCAT: Implications for reindeer herding. Ecol. Appl. 2010, 20, 2346-2358. [CrossRef] [PubMed]

24. Bartsch, A. Ten Years of SeaWinds on QuikSCAT for Snow Applications. Remote Sens. 2010, 2, 1142-1156. [CrossRef]

25. Langlois, A.; Johnson, C.A.; Montpetit, B.; Royer, A.; Blukacz-Richards, E.A.; Neave, E.; Dolant, C.; Roy, A.; Arhonditsis, G.; Kim, D.K.; et al. Detection of rain-on-snow (ROS) events and ice layer formation using passive microwave radiometry: A context for Peary caribou habitat in the Canadian Arctic. Remote Sens. Environ. 2017, 189, 84-95. [CrossRef]

26. Vuyovich, C.M.; Jacobs, J.M.; Hiemstra, C.A.; Deeb, E.J. Effect of spatial variability of wet snow on modeled and observed microwave emissions. Remote Sens. Environ. 2017, 198, 310-320. [CrossRef]

27. Semmens, K.A.; Ramage, J.M. Recent changes in spring snowmelt timing in the Yukon River basin detected by passive microwave satellite data. Cryosphere 2013, 7, 905-916. [CrossRef]

28. Tedesco, M. Snowmelt detection over the Greenland ice sheet from SSM/I brightness temperature daily variations. Geophys. Res. Lett. 2007, 34, 1-6. [CrossRef]

29. Wang, L.; Derksen, C.; Brown, R. Detection of pan-Arctic terrestrial snowmelt from QuikSCAT, $2000-2005$. Remote Sens. Environ. 2008, 112, 3794-3805. [CrossRef]

30. Wang, L.; Toose, P.; Brown, R.; Derksen, C. Frequency and distribution of winter melt events from passive microwave satellite data in the pan-Arctic, 1988-2013. Cryosphere 2016, 10, 2589-2602. [CrossRef]

31. Dolant, C.; Langlois, A.; Montpetit, B.; Brucker, L.; Roy, A.; Royer, A. Development of a rain-on-snow detection algorithm using passive microwave radiometry. Hydrol. Process. 2016, 30, 3184-3196. [CrossRef]

32. Gong, D.-Y.; Ho, C.-H. The Siberian High and climate change over middle to high latitude Asia. Theor. Appl. Climatol. 2002, 72, 1-9. [CrossRef]

33. Herren, P.A.; Eichler, A.; Machguth, H.; Papina, T.; Tobler, L.; Zapf, A.; Schwikowski, M. The onset of Neoglaciation 6000 years ago in western Mongolia revealed by an ice core from the Tsambagarav mountain range. Quat. Sci. Rev. 2013, 69, 59-68. [CrossRef]

34. Olson, D.M.; Dinerstein, E.; Wikramanayake, E.D.; Burgess, N.D.; Powell, G.V.N.; Underwood, E.C.; D'amico, J.A.; Itoua, I.; Strand, H.E.; Morrison, J.C.; et al. Terrestrial Ecoregions of the World: A New Map of Life on Earth. Bioscience 2001, 51, 933. [CrossRef]

35. Kawanishi, T.; Sezai, T.; Ito, Y.; Imaoka, K.; Takeshima, T.; Ishido, Y.; Shibata, A.; Miura, M.; Inahata, H.; Spencer, R.W. The Advanced Microwave Scanning Radiometer for the Earth observing system (AMSR-E), NASDA's contribution to the EOS for global energy and water cycle studies. IEEE Trans. Geosci. Remote Sens. 2003, 41, 184-193. [CrossRef]

36. Imaoka, K.; Kachi, M.; Kasahara, M.; Ito, N.; Nakagawa, K.; Oki, T. Instrument performance and calibration of AMSR-E and AMSR2. Int. Arch. Photogramm. Remote Sens. Spat. Inf. Sci. ISPRS Arch. 2010, 38, 13-18.

37. Du, J.; Kimball, J.S.; Shi, J.; Jones, L.A.; Wu, S.; Sun, R.; Yang, H. Inter-calibration of satellite passive microwave land observations from AMSR-E and AMSR2 using overlapping FY3B-MWRI sensor measurements. Remote Sens. 2014, 6, 8594-8616. [CrossRef]

38. Brodzik, M.J.; Billingsley, B.; Haran, T.; Raup, B.; Savoie, M.H. EASE-Grid 2.0: Incremental but Significant Improvements for Earth-Gridded Data Sets. ISPRS Int. J. Geo-Inf. 2012, 1, 32-45. [CrossRef]

39. Dietz, A.J.; Conrad, C.; Kuenzer, C.; Gesell, G.; Dech, S. Identifying changing snow cover characteristics in central Asia between 1986 and 2014 from remote sensing data. Remote Sens. 2014, 6, 12752-12775. [CrossRef] 
40. Berner, L.T.; Jantz, P.; Tape, K.D.; Goetz, S. Tundra plant aboveground biomass and shrub dominance mapped across the North Slope of Alaska. Environ. Res. Lett. 2018, 13, 035002. [CrossRef]

41. Nandintsetseg, B.; Shinoda, M.; Erdenetsetseg, B. Contributions of multiple climate hazards and overgrazing to the 2009/2010 winter disaster in Mongolia. Nat. Hazards 2017, 92, 109-126. [CrossRef]

42. Robinson, N.P.; Allred, B.W.; Jones, M.O.; Moreno, A.; Kimball, J.S.; Naugle, D.E.; Erickson, T.A.; Richardson, A.D. A Dynamic Landsat Derived Normalized Difference Vegetation Index (NDVI) Product for the Conterminous United States. Remote Sens. 2017, 9, 863. [CrossRef]

43. Hansen, B.B.; Isaksen, K.; Benestad, R.E.; Kohler, J.; Pedersen, Å.; Loe, L.E.; Coulson, S.J.; Larsen, J.O.; Varpe, $\varnothing$. Warmer and wetter winters: Characteristics and implications of an extreme weather event in the High Arctic. Environ. Res. Lett. 2014, 9, 114021. [CrossRef]

44. Minderlein, S.; Menzel, L. Evapotranspiration and energy balance dynamics of a semi-arid mountainous steppe and shrubland site in Northern Mongolia. Environ. Earth Sci. 2014, 73, 593-609. [CrossRef]

45. Munkhjargal, M.; Groos, S.; Pan, C.G.; Yadamsuren, G.; Yamkin, J.; Menzel, L. Multi-Source Based Spatio-Temporal Distribution of Snow in a Semi-Arid Headwater Catchment of Northern Mongolia. Geosciences 2019, 9, 53. [CrossRef]

46. Sen, P.K. Estimates of the Regression Coefficient Based on Kendall's Tau. J. Am. Stat. Assoc. 1968, 63, 1379-1389. [CrossRef]

47. Kim, Y.; Kimball, J.S.; Robinson, D.A.; Derksen, C. New satellite climate data records indicate strong coupling between recent frozen season changes and snow cover over high northern latitudes. Environ. Res. Lett. 2015, 10, 1-10. [CrossRef]

48. Tao, S.; Fang, J.; Zhao, X.; Zhao, S.; Shen, H.; Hu, H.; Tang, Z.; Wang, Z.; Guo, Q. Rapid loss of lakes on the Mongolian Plateau. Proc. Natl. Acad. Sci. USA 2015, 112, 2281-2286. [CrossRef]

49. Meinander, O.; Kazadzis, S.; Arola, A.; Riihelä, A.; Räisänen, P.; Kivi, R.; Kontu, A.; Kouznetsov, R.; Sofiev, M.; Svensson, J.; et al. Spectral albedo of seasonal snow during intensive melt period at Sodankylä, beyond the Arctic Circle. Atmos. Chem. Phys. 2013, 13, 3793-3810. [CrossRef]

50. Wilson, R.R.; Bartsch, A.; Joly, K.; Reynolds, J.H.; Orlando, A.; Loya, W.M. Frequency, timing, extent, and size of winter thaw-refreeze events in Alaska 2001-2008 detected by remotely sensed microwave backscatter data. Polar Biol. 2013, 36, 419-426. [CrossRef]

51. Komatsu, G.; Brantingham, P.J.; Olsen, J.W.; Baker, V.R. Paleoshoreline geomorphology of Böön Tsagaan Nuur, Tsagaan Nuur and Orog Nuur: The Valley of Lakes, Mongolia. Geomorphology 2001, 39, 83-98. [CrossRef]

52. Zhang, Y.; Ishikawa, M.; Ohata, T.; Oyunbaatar, D. Sublimation form thin snow cover at the edge of the Eurasian cryosphere of Mongolia. Hydrol. Process. 2008, 22, 3564-3575. [CrossRef]

53. Freudiger, D.; Kohn, I.; Seibert, J.; Stahl, K.; Weiler, M. Snow redistribution for the hydrological modeling of alpine catchments. Wiley Interdiscip. Rev. Water 2017, 4, e1232. [CrossRef]

54. Middleton, N.; Rueff, H.; Sternberg, T.; Batbuyan, B.; Thomas, D. Explaining spatial variations in climate hazard impacts in western Mongolia. Landsc. Ecol. 2015, 30, 91-107. [CrossRef]

55. Tachiiri, K.; Shinoda, M.; Klinkenberg, B.; Morinaga, Y. Assessing Mongolian snow disaster risk using livestock and satellite data. J. Arid Environ. 2008, 72, 2251-2263. [CrossRef]

56. Cohen, J.L.; Furtado, J.C.; Barlow, M.A.; Alexeev, V.A.; Cherry, J.E. Arctic warming, increasing snow cover and widespread boreal winter cooling. Environ. Res. Lett. 2012, 7, 014007. [CrossRef]

57. Wang, X.; Wu, C.; Wang, H.; Gonsamo, A.; Liu, Z. No evidence of widespread decline of snow cover on the Tibetan Plateau over 2000-2015. Sci. Rep. 2017, 7, 1-10. [CrossRef]

58. Ye, H.; Fetzer, E.J.; Wong, S.; Lambrigtsen, B.H. Rapid decadal convective precipitation increase over Eurasia during the last three decades of the 20th century. Sci. Adv. 2017, 3, e1600944. [CrossRef]

59. Kim, Y.; Kimball, J.S.; Du, J.; Schaaf, C.; Kirchner, P. Quantifying the effects of freeze-thaw transitions and snowpack melt on land surface albedo and energy exchange over Alaska and Western Canada. Environ. Res. Lett. 2018, 13, 075009. [CrossRef]

60. Wang, K.; Jafarov, E.; Overeem, I.; Romanovsky, V.; Schaefer, K.; Clow, G.; Urban, F.; Cable, W.; Piper, M.; Schwalm, C.; et al. A synthesis dataset of permafrost-affected soil thermal conditions for Alaska, USA. Earth Syst. Sci. Data 2018, 10, 2311-2328. [CrossRef]

61. Chen, X.; Liu, L.; Bartsch, A. Detecting soil freeze/thaw onsets in Alaska using SMAP and ASCAT data. Remote Sens. Environ. 2019, 220, 59-70. [CrossRef] 
62. Dashtseren, A.; Ishikawa, M.; Iijima, Y.; Jambaljav, Y. Temperature regimes of the active layer and seasonally frozen ground under a forest-steppe mosaic, Mongolia. Permafr. Periglac. Process. 2014, 25, 295-306. [CrossRef]

63. Walther, M.; Dashtseren, A.; Kamp, U.; Temujin, K.; Meixner, F.; Pan, C.G.; Gansukh, Y. Glaciers, Permafrost and Lake Levels at the Tsengel Khairkhan Massif, Mongolian Altai, During the Late Pleistocene and Holocene. Geosciences 2017, 7, 73. [CrossRef]

64. Murphy, D.J. Booms and Busts: Asset Dynamics, Disaster, and the Politics of Wealth in Rural Mongolia. Econ. Anthropol. 2014, 1, 104-123.

65. Nandintsetseg, B.; Shinoda, M.; Du, C.; Munkhjargal, E. Cold-season disasters on the Eurasian steppes: Climate-driven or man-made. Sci. Rep. 2018, 8, 14769. [CrossRef] [PubMed]

66. Berger, J.; Hartway, C.; Gruzdev, A.; Johnson, M. Climate Degradation and Extreme Icing Events Constrain Life in Cold-Adapted Mammals. Sci. Rep. 2018, 8, 1156. [CrossRef]

(C) 2019 by the authors. Licensee MDPI, Basel, Switzerland. This article is an open access article distributed under the terms and conditions of the Creative Commons Attribution (CC BY) license (http://creativecommons.org/licenses/by/4.0/). 